\title{
The genus Cycas (Cycadaceae) in India
}

\author{
A.J. Lindstrom ${ }^{1}$ and K.D. Hill ${ }^{2}$ \\ ${ }^{1}$ Nong Nooch Tropical Botanical Garden, Sattahip, Chonburi 20250, Thailand \\ ${ }^{2}$ National Herbarium of New South Wales, Royal Botanic Gardens, Mrs Macquaries Road, Sydney \\ 2000, Australia
}

\begin{abstract}
The genus Cycas is reviewed for India. Eight species are treated, one of them published for the first time (Cycas indica). The species are placed within an infrageneric classification previously outlined. Distributions of all taxa are mapped, and a key to species is provided.
\end{abstract}

\section{Introduction}

The genus Cycas is the single genus of the family Cycadaceae, itself the basal (sister) lineage of the living cycads (Stevenson 1992). It is also the sole living cycad group occurring in Asia. The only known fossil evidence for this genus is from the Eocene of China and Japan, and this, together with the occurrence of all major lineages in the genus in mainland Asia, supports a long-term presence and probable origin of this genus in that region (Hill 1995). Cycas consists of about 100 species, chiefly Indo-Chinese (about 40 species) and Australian (27 species). The genus also occurs in the Malesian region, Japan and India, extending to Micronesia and Polynesia, Madagascar and East Africa. Plants are commonly understorey shrubs in forest, woodland or savanna habitats. The cycad flora of India is relatively sparse in diversity and total numbers in comparison to Indochina and northern Australia, both of which show extensive local radiations. Seven species are known in India.

The present work is the outcome of our separate and combined studies, with a total of 2 field trips during the period 2000-2002. Herbarium collections held by A, B, BM, BO, E, G, K, L, LAE, NY, P and SING have been examined by at least one author. Terminology is as in previous papers in this series (e.g. Hill 1994), as are the generic and specific concepts followed. Conventions in measurements taken and presented in the following descriptions are as follows (see also Hill 2004a, b). Many of the measurements were made on fresh material; in a few instances these measurements are not given in the descriptions because they were omitted in the field.

- The minimum diameter of a single young and actively growing and reproductive stem can be of systematic significance; older stems can be branched or broken several times and maximum diameters are only therefore a measure of age with little systematic significance. 
- The length measured for a leaf is a combined measure of petiole plus lamina.

- Leaflet number is taken as the total number of leaflets on a leaf. Usually a number derived by counting leaflets along one side and doubling the result. Occasionally, numbers are different on each side of a leaf and both sides need to be counted.

- Distance midrib to midrib or top to top is taken as a convention to give a measure of leaflet spacing on the rachis.

- Leaflet to rachis angle is taken as a measure of the angle of insertion of the leaflets i.e. whether leaflets are angled forward as in C. angulata or not as in C. basaltica. Measured in the plane of one rank of leaflets.

- Leaflet angle to opposing leaflets is taken as a measure of the degree of keeling present in the leaf profile. The angle between the two ranks of leaflets.

- Pinna insertion is described as twisted when insertion is not in a parallel plane to rachis.

- The male sporophyll is typically terminated by a sterile extension. This usually consists of a flat sterile extension lying approximately in the plane of the fertile area, and a sharply differentiated apical spine, usually sharply upturned (see Fig. 3). Measurements for the two distinct parts are usually given separately, but the two may merge together (e.g. C. nathorstii below) or the apical spine may be absent (e.g. in some of the Chinese and Vietnamese species, not treated here).

- In the female sporophyll, the length of the lamina is the measurement from the last ovule to the tip, including any apical spine present.

\section{Conservation}

Populations of many Asian species appear to have declined, sometimes dramatically, over the past century. However, there is no comparative data to support this impression, and evidence for the decline is largely anecdotal and circumstantial. Several causative factors for this decline can be observed in action today, however, even though quantitative data on the effects are not available. Two principal threats to cycads exist in India at present, habitat loss and selective removal of plants from the wild for trade or utilisation. Some but not all species occur in reserved areas already proclaimed, but enforcement within these areas is sometimes difficult. There is, however, a growing interest in habitat and species conservation within India, and additional reserved areas are being evaluated and declared.

One Indian species (C. beddomei) was listed in the now out-of-date (for this region) IUCN 1997 Red Book of Threatened Plants (Walters \& Gillet 1998). C. beddomei is also the only Cycas species on Appendix 1 of CITES, although it is no more endangered than many other species in other countries, and probably less so than some. Species treated below are allocated provisional conservation status codes under the new coding system devised by the IUCN (IUCN 2001). Conservation status of all species is summarised in Table 1. 
Table1. Conservation status of cycad species in India

\begin{tabular}{|c|c|c|c|c|c|c|c|c|}
\hline Species & $\begin{array}{l}\text { Other } \\
\text { countries }\end{array}$ & $\begin{array}{l}1997 \\
\text { Red List }\end{array}$ & Reserved & $\begin{array}{l}\text { IUCN } \\
2003 \\
\text { Status }\end{array}$ & $\begin{array}{l}\text { Pop. } \\
\text { Size }\end{array}$ & \multicolumn{2}{|c|}{$\begin{array}{l}\text { Present Range } \\
\text { decline }\left(\mathbf{k m}^{2}\right)\end{array}$} & $\begin{array}{l}\text { Hab. } \\
\text { reduct. } \\
(\%)\end{array}$ \\
\hline C. annakailensis & & - & - & DD & $?$ & low & $?$ & $?$ \\
\hline C. beddomei & & E & - & $C R$ & $?$ & low & 50 & $?$ \\
\hline C. circinalis & & - & $y$ & $\mathrm{DD}$ & $?$ & $?$ & 500 & $?$ \\
\hline C. indica & & - & - & DD & $?$ & $?$ & $?$ & $?$ \\
\hline C. nathorstii & Sri Lanka & - & - & EN/NU & $?$ & $?$ & $?$ & $?$ \\
\hline C. pectinata & $\begin{array}{l}\text { Vietnam } \\
\text { China } \\
\text { Thailand }\end{array}$ & - & $y$ & $\mathrm{VU} A 2 \mathrm{C}$ & $>10,000$ & low & $?$ & $?$ \\
\hline C. spherica & & - & - & DD & $?$ & $?$ & $?$ & $?$ \\
\hline C. zeylanica & Sri Lanka & - & $y$ & VU/EX? & $?$ & $?$ & $?$ & $?$ \\
\hline
\end{tabular}

\section{Taxonomic history}

The first species of Cycas described was C. circinalis from India (Linnaeus 1753). Of the eight references cited by Linnaeus in the protologue, only two refer to C. circinalis as now typified. The other species covered by Linnaeus' description are now known as $C$. revoluta Thunb., separated by Thunberg (1784: 229), and C. rumphii Miq., separated by Miquel (1839: 45). The latter is part of a widespread species complex (see Hill 1994), all species of which have been subsequently treated as part of $C$. circinalis at some time or other.

Next to be described was C. pectinata (Hamilton 1826), followed soon by C. spherica (Roxburgh 1832), although Roxburgh was under a considerable misapprehension concerning the entities he was describing (de Laubenfels \& Adema 1998). C. beddomei was recognised half a century later (Thiselton-Dyer 1881) and C. nathorstii another half century after (Schuster 1932).

The account by de Laubenfels and Adema (1998) records four species from India, C. circinalis, C. beddomei, C. spherica and C. pectinata. C. nathorstii is included in the synonymy of $C$. circinalis and $C$. spherica, and their interpretation of $C$. thouarsii Gaudich. ex R. Br. includes material treated below under C. zeylanica. Singh added C. annakailensis in 2006 .

\section{Taxonomic treatment}

CYCAS L., Sp. Pl.: 1188 (1753).

Lectotype: C. circinalis L.; designated by Stevenson in Jarvis et al. (1993).

Dioecious palm-like shrubs with aerial or subterranean, pachycaul, cylindrical stems clad with persistent leaf-bases. Leaves loosely pubescent when young, pinnate, spirally arranged, produced in seasonal growth flushes interspersed with cataphylls, lower leaflets often reduced to spines. Longitudinal ptyxis erect or rarely reflexed, horizontal ptyxis circinate. Leaflets with a single thick midrib and no lateral veins; stomata confined to abaxial surface in most species; individual ptyxis involute. Trichomes transparent, branched or simple. Leaves with vascular traces girdling stems, girdling 
traces not present in cataphylls or megasporophlls. Microsporophylls aggregated into determinate cones and bearing numerous microsporangia (pollen-sacs) on abaxial surfaces, with a simple sterile apex, which is often produced into an upturned spine; microsporangia opening by slits; pollen cymbiform, monosulcate. Megasporophylls spirally arranged in an indeterminate terminal rosette with the central axis continuing vegetative growth. Ovules two to many (rarely one), marginally inserted on the stipe and directed obliquely outwards ('ascending'); sporophyll apically dilated into a pinnatifid, pectinate, toothed or entire lamina. Seeds with a yellow, orange or brown fleshy outer sarcotesta, and with or without spongy tissue beneath the inner woody sclerotesta. Endosperm haploid, derived from the female gametophyte. Embryo straight; with 2 cotyledons that are usually united at the tips and a very long, spirally twisted suspensor; seeds platyspermic; germination cryptocotylar.

Four sections have been recognised (Hill 1995), although there has been disagreement on subgeneric division (Wang 1996; de Laubenfels 1998), and, in the light of improved understanding of the genus, none of the proposed systems would appear entirely adequate (Hill 1998; 2004a, b). Two clear groups, regarded below a sections, occur naturally in India, and a third is represented by one widely cultivated species.

\section{Key to sections}

1 Ovules tomentose

Section Asiorientales

$1^{\star}$ Ovules glabrous

2 Megasporophyll pectinate

Section Indosinenses

$2^{\star}$ Megasporophyll entire or dentate, not deeply pectinate Section Cycas

\section{Key to species}

1 Ovules and seeds tomentose; leaflet margins strongly recurved \#C. revoluta

1 Ovules and seeds glabrous; leaflet margins not strongly recurved

2 Sarcotesta with a fibrous layer

3 Megasporophyll apex about as broad as long, lateral teeth more than $10 \mathrm{~mm}$ long 1. C. pectinata

$3^{\star}$ Lateral teeth of megasporophyll less than $6 \mathrm{~mm}$ long. 2. C. beddomei

$2 *$ Sarcotesta lacking a fibrous layer

4 Spongy endotesta absent

5 Apical spine of megasporophyll not distinctly different from lateral spines, $1-3 \mathrm{~mm}$ long . 7. C. indica

$5^{\star}$ Apical spine of megasporophyll distinctly different from lateral spines, more than $3 \mathrm{~mm}$. long

6 Lateral teeth less than $5 \mathrm{~mm}$ long

7 New growth bluish. 3. C. circinalis

$7{ }^{\star} \mathrm{New}$ growth bright green 6. C. nathorstii

$6^{*}$ Lateral teeth $5-10 \mathrm{~mm}$ long 
8 Microsporophyll 28-43 mm long; leaves with 55-130 leaflets. 4. C. spherica $8{ }^{\star}$ Microsporophyll 63-83 mm long; leaves with 200-240 leaflets

5. C. annakailensis

$4^{\star}$ Spongy endotesta within the sclerotesta

8. C. zeylanica

\# This species, native to Japan and China and belonging to Section Asiorientales, is widely cultivated throughout Asia. It is not discussed any further in this treatment.

Cycas section Indosinenses Schuster, Pflanzenr. 99: 65 (1932). Type: C. siamensis Miq., lecto, fide Hill and Yang (1998). This is one of only two species included in this section by Schuster, and the single species remaining when the other species (C. micholitzii) is removed to section Stangerioides, as was done by Smitinand (1971).

Section Indosinenses is defined by the combination of glabrous ovules, a deeply pectinate megasporophyll lamina, and the presence of a layer of fibrous tissue within the sarcotesta. It is a taxonomically complex group, ranging from Himalayan India east to Vietnam and southern China and south to northern peninsular Malaysia, with a radiation of species in Thailand (Hill \& Yang 1998). Sectional circumscription herein follows Wang (1996). One species occurs in India (Fig. 1).

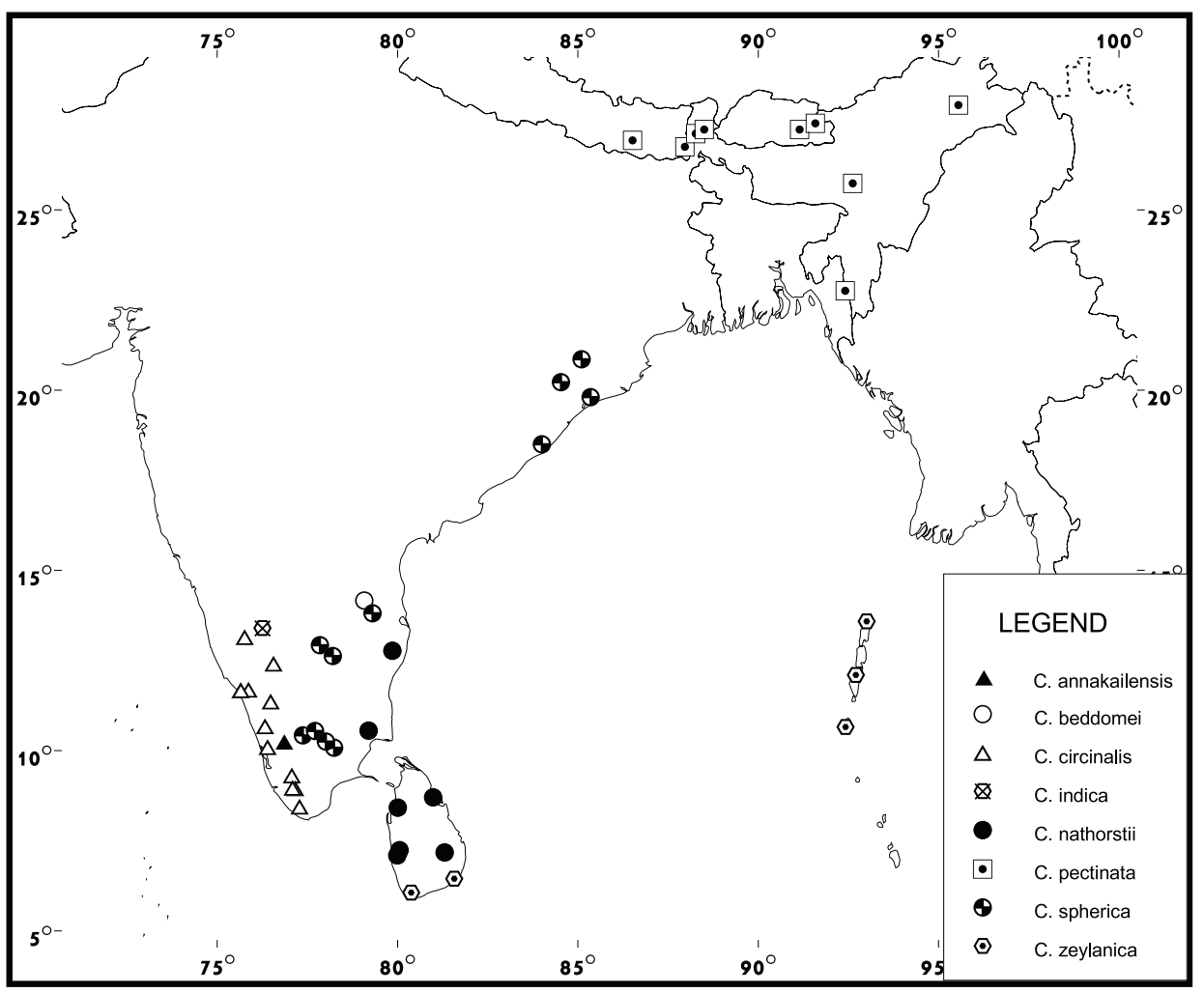

Fig. 1. Distribution of the genus Cycas in India. 
1. Cycas pectinata Buch.-Ham., Mem. Wern. Nat. Hist. Soc. 5(2): 322-323 (1826). Cycas circinalis subsp. vera var. pectinata (Griff.) Schuster, Pflanzenr. 99: 68 (1932).

Type: India, E. Bengal, Chittagong, J.D. Hooker \& Thompson 6, 1855 (neo K!, isoneo P!). This specimen was designated the lectotype by de Laubenfels and Adema (1998), but this cannot be maintained since the specimen was collected after the species was published. The same specimen has been designated the neotype (fide Hill et al. 2004).

Cycas pectinata Griff., Not. Pl. Asiat. 4: 10 (1854); Ic. Pl. Asiat. 4: Plate 360, fig. 3 (1854); nom. illegit., later homonym of C. pectinata Buch.-Ham. (Mem. Wern. Nat. Hist. Soc. 5(2): 322. 1826). Type: Icones Plantarum Asiatarum 4: Plate 360, fig. 3. (1854).

Cycas jenkinsiana Griff., Not. pl. Asiat. 4: 9-10, Plates 360, fig. 1-2 and 362, fig. 1 (1854). Type: India, Assam, Jenkins s.n. (holo K!; iso BM!, L!).

Literature: Kurz (1877), Leandri (1931), Schuster (1932), Ho \& Duong (1960), Raizada \& Sahni (1960), Suvatabandhu (1961), Smitinand (1971), Grierson \& Long (1983), Wang (1996), Tang et al. (1997), Chen and Stevenson (1999), Hill \& Yang (1998).

Illustrations: Smitinand (1971), Cheng, Fu \& Cheng (1975), Grierson \& Long (1983), Wang (1996), Tang et al. (1997), Hill \& Yang (1998).

Etymology: Latin pectina, a comb, in reference to the long, comb-like teeth of the megasporophylls.

Vernacular: Assam - thaljimura, Burmese - môndaing, Chinese - bi-chi su-tie (cycad with comb - like megasporophylls), feng-wei-jiao (Phoenix-tail grass or palm), fenghuang-dan, Khasi - dieng-sia-goda, Nepalese - thakal, thaljimura, Thai - boka, plong, prong khao, prong pa (forest or field cycad) (Chen et al. 1995, Hill \& Vatcharakorn 1998, Pant 1962, Pant et al. 1994, Smitinand 1972, Walters \& Yang 1994, Bonta \& Osborne 2005).

Stems arborescent, to 1-12 m tall, 14-20 cm diam., (with 30-40 leaves in crown); growing in soil or humus; base not strongly swollen; bark thin and smooth, cataphylls and leaf bases not persistent. Leaves deep green to grey-green, semiglossy, 150-240 cm long, flat (not keeled) in section (opposing leaflets inserted at $170-180^{\circ}$ on rachis), with 180-312 leaflets, with white tomentum shedding as leaf expands, rachis consistently terminated by a spine $1-46 \mathrm{~mm}$ long. Petiole $30-80 \mathrm{~cm}$ long (25-50\% of total leaf), glabrous, spinescent for $30-80 \%$ of length. Basal leaflets not gradually reducing to spines, 50-160 mm long. Median leaflets simple, strongly discolorous, $200-315 \mathrm{~mm}$ long, 7.5-10.5 mm wide, inserted at $45-60^{\circ}$ to rachis, decurrent for $4-8 \mathrm{~mm}$, narrowed to $2.5-4 \mathrm{~mm}$ at base (to $35-45 \%$ of maximum width), $8-13 \mathrm{~mm}$ apart on rachis, section flat, margins slightly recurved; apex acute, sometimes spinescent; midrib raised above, raised below. Cataphylls narrowly triangular, soft, pilose, 70-90 mm long. Pollen cones ovoid, yellow or green, 30-55 cm long, 16-22 cm diam.; microsporophyll lamina firm, not dorsiventrally thickened, 43-60 mm long, 19-24 mm wide, fertile zone 35-57 mm long, sterile apex 3-8 $\mathrm{mm}$ long; apical spine prominent, sharply upturned, 17-32 $\mathrm{mm}$ long. Seed cones closed at pollination, closed as seed set. Megasporophylls $22-30 \mathrm{~cm}$ long, grey-tomentose, tomentum shedding on older megasporophylls; ovules 2-4, glabrous; lamina orbicular, 110-180 mm long, 100-130 mm wide, deeply pectinate, with 40-50 soft lateral spines $26-75 \mathrm{~mm}$ long, 2-3 mm wide; apical spine distinct from lateral spines, 35-75 mm long, 5-12 $\mathrm{mm}$ wide at base. Seeds flattened-ovoid, 42-45 mm long, 33-45 mm wide; sarcotesta yellow, (not pruinose, 4-7 $\mathrm{mm}$ thick), fibrous layer present; sclerotesta smooth; spongy layer absent. 
Historical notes: Cycas pectinata was the fourth species of Cycas to be named, described in 1826 by Scottish surgeon and botanist Francis Buchanan-Hamilton (1762-1829), who worked as a surgeon in the Bengal medical service (1795-1815) and was superintendent of the Botanical Garden Calcutta (1814-1815). No type was cited, but reference was made to occurrence in "the hills which bound Bengal to the east", and the description cited "Habitat in Camrupae orientalis sylvis". C. angulata R.Br. and Olus calappoides of Rumphius (C. rumphii Miq.) were cited (erroneously) in synonymy (Hamilton 1826). Zhou et al. (1990) regarded Hamilton's publication as illegitimate because C. angulata was cited as a synonym. The latter was cited, but with a question mark, indicating that the author was unsure of the placement of $C$. angulata. This does not invalidate Hamilton's publication (see McNeill et al. 2006, Art. 52.2, note 1, example 9). The primary set of Hamilton's Bengal collections eventually went to Wallich and thence to Kew $(\mathrm{K}-\mathrm{W})$. A second set went to E. Neither set includes a specimen that could be regarded as the type of $C$. pectinata.

The name has been attributed to Griffith (Griffith 1854a, b), although he did not actually add his name to the binomial when describing it (Griffith's practice apparently was to add his name to new binomials, and place no name on existing or previously published binomials).

Distinguishing features: the very large, ovoid male cones with long, narrow microsporophylls, those with long apical spines, readily distinguish this species from others in the C. pectinata group. The thin, smooth bark also distinguishes this species from related taxa, although this feature is shared with C. clivicola K.D.Hill and C. elongata (Leandri) D.Yue Wang.

Distribution and habitat: common and widespread in forest on hills of the south-eastern Himalayas, mostly above about $500 \mathrm{~m}$ altitude (Fig. 1). This species occurs in medium to tall forest on deep, often clay-rich and more fertile soils, usually as part of the general shrub under storey at medium to higher elevations in generally moist conditions. in moderate to deep shade. Although often found on soil overlaying limestone substrates, it is by no means restricted to these, and also occurs on granites and metasediments.

C. pectinata is abundant in the hill forests of north-eastern India, and has also been collected from Nepal and Bhutan. It extends into Yunnan Province in southern China, and east into northern Thailand, Laos and Vietnam.

Conservation status: an abundant and widespread species. Although its habitat is continually being reduced, large populations remain, and it is not under any immediate threat of extinction. IUCN status VU A2c (Donaldson 2003) (on the basis of the continuing population decline, although the very large populations remaining indicate that the short-term threat of extinction is low).

Selected specimens: INDIA: Gowatty, Clark 43243, 29 Mar 1886 (K); Satte Bhaia Jhai, Darij Serai, Gamble 2675A, Jan 1875 (K); Rammagar Hills, Haines 3983, Nov 1916 (K); Great Rungeet Valley, Sikkim, Hooker s.n., 1848 (K); Khasia, Hooker \& Thompson, 16 Jul 1850 (K); Laki, Lakhei County, Lushai Hills, Assam, Parry 100, Feb 1927 (K); Koongi Valley, Manipur, Watt 6796, 27 Apr 1882 (K). BANGLADESH: Chittagong, Hooker \& Thompson Herb. Ind. Or (BM, K, L); Satakoina, Chittagong, Hooker \& Thompson 595, 11 Jan 1857 (K). BHUTAN: E bank of Dangme Chu, between Cha Zam and Duksun, N of Tashigang, Grierson \& Long 2357, 29 Jun 1979 (K ex E). BURMA: Shan States, Aplin s.n., Nov-Dec 1887 (K); Mundat, Kingdon Ward 22308, 18 May 1956 (K); Rangoon, Meebold 8166, Jan 1908 (K). CHINA: Yunnan, Henry 13637 (K, NY); Meng Yuan district, Meng La Natural Reserve, Lindstrom s.n., 1994 (no voucher). 
NEPAL: Mechizou Jhapa district, Nicolson 3078, 31 Mar 1967 (BM); Ganjbari (26 45’N 87 58'E), Stainton 5733, 1 Apr 1967 (BM); Udaipur Ganhi (26 56’N 86 31’E), Stainton 6638, 3 Nov 1969 (BM). THAILAND: Chaiyaphum: near Chulaphorn Dam, Larsen, Supee, Larsen, Nielsen \& Santisuk 31432, 5 Aug 1972 (BKF). Chiang Mai: Doi Pha Hom Pok, Fang, Kerr 5218, 3 Apr 1921 (BM, K). Kanchanaburi: Ban Huay Sue, E of Thong Pha Phum, Hill 4645, 02 May 1994 (NSW, BKF, K, L, PE). Loei: Phu Paek, van Beusekom \& Phengklai 3027, 14 Jan 1970 (L ex BKF). Mae Hong Son: Ban Mok Jum Prak, Hill 4638, 26 Apr 1994 (NSW). Phetchabun: N of Chai Badun, Abbe, Abbe \& Smitinand 9361 B, 2 Jan 1960 (BKF). Phrae: Mae Kating, Williams \& Smitinand 17133 (BKF). Sukhothai: Khao Luang, Kerr 5944, 4 May 1922 (BM, K). VIETNAM: Gia Lai: Kbang (1404'N 10840'E), 30 Oct 1994, Yang 532, Ban \& Lindstrom (HN); Dalat, 5 Nov 1994, Yang 542, 543, Ban \& Lindstrom (HN). Kon Tum: between Dak Poko and Dak Mek rivers, 1000 m alt, 28 Mar 1995, US Nat. Geog. Soc. Exped. VH 962, 963 (HN); Quang Ngai: Duc Pho, pho Khanh, 25 Jan 2000, Hiep 4162, 4163, 4164 \& Hill (HN, NSW).

\section{Cycas section Cycas}

Section Lemuricae Schuster, Pflanzenr. 99: 65 (1932), nom. illegit.

Section Cycas is defined by the combination of glabrous ovules and a non-pectinate megasporophyll lamina. Three subsections are recognised, circumscription following Hill (1995), with two occurring in India. The full range of the section is from India and southern Indochina south to Australia, and from East Africa east to Tonga.

\section{Key to the Subsections}

1 Seeds with a spongy layer inside the sclerotesta Subsection Rumphiae $1^{\star}$ Seeds lacking a spongy layer Subsection Cycas, Subsection Endemicae (Australia and New Guinea only, not discussed further)

\section{Cycas subsection Cycas}

This subsection of about 10 species is defined by the absence of a spongy endotesta, and the long megasporophyll with a narrow lamina. It ranges from India and Sri Lanka to Luzon, south and east to New Guinea. Most representatives are plants of closed forests, usually on ridges away from the coast. Six species occur in India.

2. Cycas beddomei Dyer, Trans. Linn. Soc. London., Bot. (ser. 2) 5: 85, pl. 17 (1881). Cycas circinalis subsp. vera var. beddomei (Dyer) Schust., Pflanzenr. 99: 67 (1932).

Type: India: Cuddapah Hills, H.H. Yarde s.n., Aug. 1882 (syn K!, 3 sheets; isosyn BM!).

Literature: Raizada \& Sahni (1960).

Illustrations: Thiselton-Dyer (1881), Warburg (1900).

Etymology: honouring Colonel Richard Henry Beddome (1830-1911), a director of the Lal Bagh, or government gardens, at Bangalore and author of the 'Foresters manual of botany for southern India'.

Vernacular: telugu - per ita, madhana - kamakshi (lit. lust-eyed one, presumably ref. to aphrodisiac properties), unidentified lang. - konda itha (Fischer 1928, Schuster 1932, Raizada \& Sahni 196, Whitelock 2002, Bonta \& Osborne 2005). 
Stems arborescent, to $2 \mathrm{~m}$ high, $12-23 \mathrm{~cm}$ diam., often suckering at the base; usually growing in soil or humus; base not strongly swollen; bark thick, corky, cataphylls and leaf bases persistent. Leaves grey-green, dull, c. $90 \mathrm{~cm}$ long, flat (not keeled) in section (opposing leaflets inserted at $180^{\circ}$ on rachis) with brown tomentum shedding as leaf expands. Petiole c. $15 \mathrm{~cm}$ long 20-30\% of total leaf), glabrous, spinescent. Basal leaflets not gradually reducing to spines, Median leaflets simple, strongly discolorous, $100-175 \mathrm{~mm}$ long, $2-4 \mathrm{~mm}$ wide, inserted at $50-60^{\circ}$ to rachis, narrowed to $1.5-2.5 \mathrm{~mm}$ at base (to $60-75 \%$ of maximum width), $4-6 \mathrm{~mm}$ apart on rachis; section slightly keeled; margins revolute; apex acute or aristate, spinescent; midrib raised above, flat below. Cataphylls narrowly triangular, soft, thinly sericeous or lacking tomentum, 50-70 mm long. Pollen cones narrowly ovoid, orange, c. $30 \mathrm{~cm}$ long, c. $7.5 \mathrm{~cm}$ diam.; microsporophyll lamina firm, not dorsiventrally thickened, c. $35 \mathrm{~mm}$ long, c. $15 \mathrm{~mm}$ wide, fertile zone c. $30 \mathrm{~mm}$ long, sterile apex c. $5 \mathrm{~mm}$ long, merging with spine; apical spine prominent, gradually raised, c. $30 \mathrm{~mm}$ long. Seed cones open at pollination, open at seed set. Megasporophylls 15-20 cm long, persistently brown-tomentose; ovules 2, glabrous; lamina lanceolate, 65-75 mm long, 20-25 mm wide, regularly dentate with 22-32 pungent lateral spines 5-9 $\mathrm{mm}$ long, $1 \mathrm{~mm}$ wide; apical spine distinct from lateral spines, 11-15 $\mathrm{mm}$ long , 2$3 \mathrm{~mm}$ wide at base. Seeds flattened-ovoid, 34-38 mm long, 30-34 mm wide; sarcotesta yellow, fibrous layer present; sclerotesta smooth; spongy endotesta absent.

Historical notes: described by English botanist Sir William Turner Thiselton-Dyer (1843-1928), Assistant Director at Kew from 1875-1885 and Director from 1885-1905.

The presence of this distinctive species was first observed by Beddome (1869), who recorded it (with some hesitation) as C. revoluta Thunb. Thiselton-Dyer next noted in an popular article in Gardeners Chronicle in 1881 that a small-growing Indian species that was distinct from $C$. circinalis had several times been introduced into horticulture in Europe, under a variety of names. The first introduction was by Colonel Beddome, who sent plants to Belgian Nurserymen during his term as Director of the Government Gardens at Bangalore. These nurserymen applied the name C. boddami to the plants. The second introduction was by Adolf Haage of Erfurt, who gave the locality as Travancore. These introductions had the name C. squamosa applied to them. The third introduction was of plants collected by Colonel Puckle, another director of the Lal Bagh (Government Gardens) at Bangalore, and imported by the English plant trader William Bull in 1877, who described it is his catalogue as 'a distinct Indian cycad, from the Presidency of Madras', under the name C. pluma. Thiselton-Dyer, while recording this history, appealed to readers (of Gardener's Chronicle) in southern India for botanical specimens from the wild, in order to establish the true relationships of this plant.

His pleas were answered by H.H. Yarde, the Deputy Conservator of Forests for the Cuddapah division, who sent both plants and botanical specimens. This allowed Thiselton-Dyer to recognise that this was a distinct species, and he described it as C. beddomei in 1883. Yarde apparently sent only juvenile plants, causing Thiselton-Dyer to firstly record that he had only seen stems a few inches high, and later (1888) to state categorically that stems were only a few inches high. The myth that this species was almost stemless was propagated in the literature from there, for example by Fischer (1928), Schuster (1932) and Raizada and Sahni (1960).

This species has been one of the few in the genus that has been fairly clearly understood from its beginning, with little misapplication of the name and no misunderstanding of the type. Schuster (1932) treated it as a variety of C. circinalis, to which it is clearly 
closely related. However, he showed little understanding of the limits of C. circinalis, and included material from Java within his variety beddomei. Raizada \& Sahni (1960) included material from the eastern Ghats that had been earlier separated as $C$. circinalis var. orixensis and C. spherica under C. beddomei. The Eastern Ghats material is, however, quite distinct from C. beddomei (see C. spherica).

Distinguishing features: this species has in common with the other southern Indian cycads a non-pectinate megasporophyll with subglobular seeds that display a distinctive fibrous layer within the sarcotesta, and an attenuate microsporophyll apex. It can be distinguished by the very narrow leaflets with revolute margins.

Distribution and habitat: known only from the Cuddapah Hills in Andhra Pradesh State, north-west of Madras in eastern Peninsular India (Fig. 1). Characteristically a species of dry, open hill slopes, in open woodland or grassland.

Conservation status: although present in considerable numbers, this species faces a number of significant threats. It is well adapted to rapid recovery after fire, but frequent grassfires effectively block reproduction by burning seeds and seedlings. An even more effective block to reproduction is the use of the male cones in Ayer Veda medicines, making them a trafficable commodity that can earn peasant villagers a few desperately needed rupees. The villagers scour the more accessible populations for cones, removing all before pollen shed. The species seems to be more widely distributed within the Cuddapah district than first thought. There are still several large undisturbed populations with annual seed production in more remote areas. However several large populations near the Tirupati have been destroyed by road work and now only exist as scattered individuals in inaccessible rock crevices. It is the only member of the genus Cycas to be listed in CITES Appendix 1, and is accorded a status of endangered. 1997 IUCN Red List of Threatened Plants category E (Walter \& Gillet 1998). It is also protected within India by a Forestry Act completely ban the cultivation of this species. IUCN status CR (Donaldson 2003).

Selected specimens examined: INDIA: Andhra Pradesh: Cuddapah distr., Mogilipunta, Gamble 21278, Aug 1889 (K); Cuddapah Hills, Higgins per Gamble 16597, 1885 (K)

3. Cycas circinalis L., Spanish Pl.: 1188 (1753).

Type: the illustration: Rheede, Hort. Malab., tab. 19, 1682 (lecto, fide Stevenson in Jarvis et al. 1993).

Cycas circinalis var. angustifolia Miq., Comm. Phyt.: 125-126 (1840-1841). Type: ex hort. bot. Calcutta, U 028096 (lecto U).

Cycas wallichii Miq., Monogr. Cycad.: 32 (1842). Type: based on Cycas circinalis var. angustifolia.

Cycas undulata Desf. ex Gaudich., Voy. Uranie, Bot.: 434 (1829). Cycas circinalis [subsp. circinalis] forma undulata (hort. ex Gaudich.) J. Schust., Pflanzenr. 99: 66 (1932). Cycas rumphii forma undulata (Desf. ex Gaudich.) Kaneh., J. Jap. Bot. 14(9): 587 (1938). Type: hort. Paris, 1820, ex herb. Houllet (holo P).

[Cycas circinalis subsp. vera J. Schust., Pflanzenr. 99: 66-67, Fig. 40; 7C; 10A, F-G; 11F (1932); nom. illegit.]

[Cycas hamelini hort. ex J. Schust., Pflanzenr. 99: 66 (1932); name only, in syn. Cycas circinalis.] 
[Cycas kirkii hort. ex J. Schust., Pflanzenr. 99: 73 (1932); name only, in syn. Cycas circinalis.]

Literature: Gaudichaud (1829), Trimen (1898), Stapf (1916), Leandri (1931), Ho \& Duong (1960), Raizada \& Sahni (1960), Suvatabandhu (1961), Smitinand (1971), Zamora \& Co (1986), Hill (1995).

Illustrations: Anon. (1828), Miquel (1842), Griffith (1854) and as C. jenkinsiana, Warburg (1900), Schuster (1932) and as C. rumphii subsp. zeylanica, Smitinand (1971), Smitinand (1972), Zamora \& Co (1986).

Etymology: from the Latin circinus, a spiral, in reference to the inrolled leaflets in developing leaves.

Vernacular: Hindi - jangli-madan-mast-ka-phul (lit. forest flower of sweet desire presumably ref. to aphrodisiac properties), Kanarese - mundicalu, Oriya - orguna, odasa-mari, Tamil - canningay (lit. convulsions of the hand, possible ref. to toxic properties), madanagama, Telugu - kamkshi, per ita, Sanskrit - varaguna (Pant 1962, Bonta \& Osborne 2005).

Stems arborescent, to $7 \mathrm{~m}$ tall, 12-27 cm diam.; growing in soil or humus; base not strongly swollen; bark thick and corky, cataphylls and leaf bases persistent. Leaves bright green, semiglossy, 150-270 cm long, flat (not keeled) in section (opposing leaflets inserted at $180^{\circ}$ on rachis), with 54-110 leaflets, tomentum shedding as leaf expands or partly persistent; newly emerging leaves with a glaucous sheen. Petiole $34-70 \mathrm{~cm}$ long (20-40\% of total leaf length), glabrous, spinescent for 30-100\% of length; basal leaflets not gradually reducing to spines. Median leaflets simple, weakly discolorous, 220-360 $\mathrm{mm}$ long, 9-13 mm wide, narrowed to $2.5-4 \mathrm{~mm}$ at base (30-40\% of maximum leaf width), 9-14 mm apart on rachis; section flat; margins flat, not undulate; apex softly acuminate, not spinescent; midrib raised above, flat below, narrow. Cataphylls narrowly triangular soft, thinly sericeous or lacking tomentum, $50 \mathrm{~mm}$ long. Pollen cones ovoid to conical, light brown to brown, 24-48 cm long, 12-18 cm diam., microsporophyll lamina firm, not dorsiventrally thickened, 45-60 mm long, 21-24 mm wide; fertile zone 40-55 mm long, sterile apex c. $5 \mathrm{~mm}$ long, merging with spine; apical spine prominent, gradually raised, 20-39 mm long. Seed cones open at pollination, open at seed set. Megasporophylls 20-35 cm long, persistently orange-tomentose; ovules 4-14, glabrous; lamina lanceolate, 27-40 mm long, 23-34 mm wide, regularly dentate, with 10-28 pungent lateral spines 1-4 mm long; apical spine distinct from lateral spines, 14-34 mm long, 3-6 mm wide at base. Seeds elongated, 30-39 mm long, 20-24 mm wide; sarcotesta light yellow, fibrous layer absent; sclerotesta smooth; spongy endotesta absent.

Historical notes: surrounded by confusion since its inception, this was described as the single constituent species when the great Swedish botanist Carolus Linnaeus established the genus Cycas in 1753. He had, however, based his description on a number of earlier works that in fact covered at least three distinct species as we now know them. The subsequent history of this name has been one of total confusion. Cycas circinalis has subsequently appeared in the literature more frequently than any other Cycas combination, arguably without a single author wholly correctly applying the name. (See Table 2 for correct placement of combinations validly published under Cycas circinalis).

Of the eight references cited by Linnaeus, only two refer to C. circinalis as now typified. This reflects an increasing understanding of the systematics of the group since the time 
of Linnaeus' work. The other species covered by Linnaeus' description are now known as C. revoluta, separated by Thunberg in 1784, and C. rumphii, separated by Miquel in 1839. The latter is part of a widespread species complex, all of which have been treated as part of $C$. circinalis at some time or other.

Table 2. Correct placement of combinations validly published under Cycas circinalis.

C. circinalis forma glauca (Miq.) Schust.

C. circinalis forma gothanii Schust.

C. circinalis subsp. madagascariensis (Miquel) Schust.

C. circinalis subsp. madagascariensis forma trigonocarpoides Schust.

C. circinalis subsp. papuana (F.Muell.) Schust.

C. circinalis subsp. papuana var. scratchleyana (F.Muell.)Schust.

C. circinalis subsp. riuminiana (Port ex Regel) Schust.

C. circinalis subsp. riuminiana var. curranii Schust.

C. circinalis subsp. riuminiana var. curranii forma apertorum Schust.

C. circinalis subsp. riuminiana var. curranii forma chamberlainii (Brown \& Keinholz) Schust.

C. circinalis subsp. riuminiana var. curranii forma graminea Schust.

C. circinalis subsp. riuminiana var. curranii forma maritima Schust.

C. circinalis subsp. seemannii (A.Braun) Schust.

C. circinalis subsp. vera var. beddomei (Dyer) Schust.

C. circinalis subsp. vera var. pectinata (Griffith) Schust.

C. circinalis subsp. thouarsii (Gaudich.) Engl.

C. circinalis var. javana Miq.

C. circinalis var. orixensis Haines
C. glauca Miq. Nom. dub.

C. thouarsii Gaudich.

C. thouarsii Gaudich.

C. papuana F.Muell.

C. scratchleyana F.Muell.

C. riuminiana Port ex Regel

C. curranii Schust.

C. riuminiana Port ex Regel

C. riuminiana Port ex Regel

C. wadei Merrill

C. edentata de Laub.

C. seemannii A. Braun

C. beddomei Dyer

C. pectinata Buch.-Ham.

C. thouarsii Gaudich.

C. javana (Miq.) de Laub

C. spherica Roxb.

Although well known in Indian culture for many centuries (Rheede 1682), the first reference to this species in Western writings was in Rheede's Hortus Malabaricus, published in Amsterdam in 1682. Although this publication has generally been accepted as the basis for this species (de Candolle 1868: 525, Stapf 1916, Wijnands 1986), it was not formally designated the type until 1993 (Jarvis et al.).

Much of the confusion associated with this species arises from the difficulty in recognising Miquel's segregate species C. rumphii, and its full geographic extent. Miquel himself had difficulty recognising the limits of these taxa (1868), and often changed his mind. Characteristics by which these species can be recognised were also not well known. The difficulty in separating the two has continued to the present (e.g. Jones 1993), and has severely reduced the usefulness and value of a number of anatomical and morphological studies based on unvouchered or cultivated materials (e.g. Dehgan \& Yuen 1983, Pant 1973). Almost all plants in cultivation that have been known as C. circinalis in fact belong to the $C$. rumphii complex. The name $C$. circinalis has also been applied uncritically to local populations in many parts of the world, without real knowledge of the true nature of typical C. circinalis. Examples of misapplication occur in Ceylon (Trimen 1898 - C. nathorstii), Thailand (Suvatabandhu 1961, Smitinand 1971, 
1972 - C. spp.), Malaysia (Gibbs 1914 - C. edentata de Laub.), The Philippines (Amoroso 1986, Foxworthy 1911, Zamora \& Co 1986 - C. riuminiana Porte ex Regel), New Guinea (Borell 1989 - C. apoa K.D. Hill; Paijmans 1976 - C. campestris K.D. Hill; White 1922 - C. scratchleyana F.Muell.) and the western Pacific (Burkill 1901, de Laubenfels 1978, Hemsley 1895, Yuncker 1959 - C. seemannii A.Braun; Fosberg \& Sachet 1975, Stone 1970 - C. micronesica K.D.Hill).

In the protologue of $C$. circinalis, Linnaeus $(1753,1754)$ cited treatments of Cycas from eight earlier works, including at least three taxa as they are currently circumscribed, but also stated 'Habitat in India'. Stapf (1916) stated '... the C. circinalis of India represented by Rheede's Todda Panna (Rheede 1682: 9, tab. 13-21), [is] the accepted basis of Linnaeus's species.' Lectotypification was discussed but not formally designated by Wijnands (1986). No specimens relating to Hortus Malabaricus are known, and one of the series of illustrations of Todda Panna by Rheede (tab. 19) has since been designated the lectotype by Stevenson in Jarvis et al. (1993).

A small population in the Annaikal hills near Palaghat has been described as Cycas annakailensis (Singh 2006, Singh \& Radha 2006). This population lies within the range of $C$. circinalis (Fig. 1.). The description of this species compares it only with C. circinalis from the state of Kerala and not across the full range of $C$. circinalis, nor with $C$. spherica or $C$. indica. In addition, many of the distinguishing features cited overlap the same features in $C$. circinalis or are variable within the latter species. The smooth trunk cited also may be a feature of a wetter habitat, which encourages residual cataphylls and leaf bases to rot away. C. annakailensis is hence here treated as a distinct taxon on the basis of leaf differences (below), although it is acknowledged that further study of this group is required, particularly in the field.

Distinguishing features: characterised by a non-pectinate megasporophyll, and an attenuate microsporophyll apex (Fig. 2). This megasporophyll morphology occurs in many other species, and is largely the cause of much of the confusion. The attenuate microsporophyll state is, however, restricted to a few species from the Indian subcontinent. The broad and long leaflets easily distinguish this species from all other Indian species. Cycas circinalis is distinguished from other Indian species by the bluish new growth.

Distribution and habitat: Cycas circinalis is now known to be an Indian endemic, restricted to the Western Ghats, in the states of Kerala, Karnataka, Tamil Nadu, and the south of Maharashtra (Fig. 1). It typically occurs in fairly dense, seasonally dry scrubby woodlands in hilly areas. Many trees in this habitat lose their leaves in the dry season, and $C$. circinalis is also facultatively deciduous in extremely dry times. It appears to be an adaptable species with colonies extending from rocky hill outcrops down to coastal habitats at sea level.

The taxon from the northern Eastern Ghats in the state of Orissa, described as C. circinalis var. orixensis by Haines (1924) and generally treated as C. circinalis, differs markedly in its megasporophylls. It in fact represents a separate species (see C. spherica).

Conservation status: locally abundant in several areas, although the habitat has been severely reduced and degraded. Good populations still exist in a number of national parks and forest reserves. The local people in Kerala do not practice the devastating cutting of stems for medicine as in Tamil Nadu and Andha Pradesh. There are several 
very large populations along the coast in Kerala that have been integrated within local villages and left undisturbed. Prolific seed set occurs and plants of every age and size class are present. IUCN status DD (Donaldson 2003).

Selected specimens examined: INDIA: Karnataka: Mangalore, Debeaux (P); Metz 169a (P); Presidency of Madras, Bellaru distr. [BELLARU, $13^{\circ} 0^{\prime} \mathrm{N}, 76^{\circ} 42^{\prime} \mathrm{E}$.], Sandui forests, Hooper per Gamble 11701, May 1883 (K). Kerala: Kingdom of Malabar, South Malabar, near Tuppanad, Fisher 2613, 27 Feb 1911 (K); Kingdom of Malabar, interior de la peninsula, Leschenault 814 (P); Quilon district, Aryankavu check point, N $08.949333^{\circ}$ E $77.15835^{\circ} 242 \mathrm{~m}$ ASL, Lindstrom 879, 880, 16 Jan 2002, (NSW); $4 \mathrm{~km}$ from Palaruri waterfall, near the railway bridge, $\mathrm{N} 8.966311667^{\circ}$ E 77.09265 $261 \mathrm{~m}$ ASL, Lindstrom 887, 16 Jan 2002 (NSW); Lindstrom 882, 885, 886, 16 Jan 2002, (NSW); Calicut district, between Kuningad and Purameri village, N 11.662115 E $75.64125^{\circ} 26$ m ASL. Lindstrom 889, 17 Jan 2002 (NSW); Calicut district, near Kuningad village, N $11.670667^{\circ}$ E 75.6497 34 m ASL, Lindstrom 891, 892, 893, 17 Jan 2002 (NSW); Cannanore, herb. Wight 2756 pp, Feb 1852 (K, P). Tamil nadu: South Travancore, Peckinpara Dam [Travancore is mainly now in Kerala, but this locality lies just across the border in Tamil Nadu, c. $8^{\circ} 20^{\prime} \mathrm{N} 77^{\circ} 20^{\prime} \mathrm{E}$ ], Ertanson 5398, 14 Feb 1934 (NY).Cult.: Calcutta, Meebold 756, Feb 1905 (G); Wallich 8587A $(\mathrm{K}-\mathrm{W})$.

4. Cycas spherica Roxb., Fl. Ind.: 747 (1832).

Type: ex hort. Calcutta, Roxburgh s.n., 1808 (lecto BM, fide Hill 1995).

Cycas circinalis var. orixensis Haines, Bot. Bihar Orissa 6: 1228 (1924). Type: India, Orissa, Mals of Puri, Haines 5876, June 1917 (syn. K); Angul, Haines 5877, July 1917 (syn. K).

Etymology: from the rounded seeds.

Stems arborescent, to $5 \mathrm{~m}$. tall, 9-27 $\mathrm{cm}$ diam.; growing in soil or humus; base not strongly swollen; bark thick with persistent leaf bases and cataphylls. Leaves dark green, semiglossy, 95-185 cm long, flat (not keeled) in section,(opposing leaflets inserted at $180^{\circ}$ on rachis), with 55-130 leaflets, with newly emerging leaves light green and lacking tomentum because tomentum sheds very early as leaf expands. Petiole 27-50 cm long (15-30\% of total leaf length), glabrous, spinescent for $20-100 \%$ of length. Basal leaflets not gradually reducing to spines. Median leaflets simple, weakly discolorous, $180-270 \mathrm{~mm}$ long, $7-12 \mathrm{~mm}$ wide, narrowed to $3-4 \mathrm{~mm}$ at base (25-60\% of maximum width), spaced at 12-22 mm on rachis; section flat; margins flat or slightly decurved, not undulate; apex softly acuminate, not spinescent; midrib raised above, raised below, narrow. Cataphylls narrowly triangular soft, thinly sericeous or lacking tomentum, 50-70 mm long. Pollen cones narrowly ovoid, orange, c. $45 \mathrm{~cm}$ long, c. $10 \mathrm{~cm}$ diam., microsporophyll lamina firm, not dorsiventrally thickened, $32-38 \mathrm{~mm}$ long; fertile zone 28-34 mm long, sterile apex c. $4 \mathrm{~mm}$ long, merging with apical spine; apical spine prominent, gradually raised, c. $17 \mathrm{~mm}$ long. Seed cones open at pollination, open at seed set. Megasporophylls 20-25 cm long, persistently orange-tomentose; ovules 3-8, glabrous; lamina lanceolate, $28-43 \mathrm{~mm}$ long, 18-20 $\mathrm{mm}$ wide, shallowly pectinate or regularly dentate, with 21-25 pungent lateral spines 5-10 $\mathrm{mm}$ long; apical spine distinct from lateral spines, 17-29 mm long, 4-5 m wide at base. Seeds subglobose, 25 $\mathrm{mm}$ long, c. $25 \mathrm{~mm}$ wide; sarcotesta yellow, fibrous layer absent; sclerotesta smooth; spongy endotesta absent.

Historical notes: Cycas spherica was first mentioned by Roxburgh in 1814, and formally described by him in 1832 . No type was cited, although reference was made 
in the description to plants in cultivation in the botanic gardens in Calcutta, which were said to have been introduced from the Moluccas in 1798-9. Cycas spherica is not known from there, although much of the description clearly applies to this species. Roxburgh had evidently confused plants of C. spherica (at the time included in C. circinalis) and C. rumphii (which had not been described at that time) that were both growing in the gardens, and his description under the former name actually applies to the latter species. His description of $C$. spherica correspondingly applies mainly to the element cultivated as $C$. circinalis. Roxburgh did not retain a personal herbarium, but distributed his collections to other botanists. Roxburgh specimens thus do not always bear the names eventually published by him (Sealy 1975). Two Roxburgh collections from the Calcutta gardens now in BM represent C. spherica and C. rumphii respectively. The latter is annotated ' $C$. circinalis', and the former bears only the annotation 'C. planifolia Solander MS.'

This taxon was also described in 1924 as a variety of the closely-related C. circinalis by English forester Henry Haselfoot Haines (1867-1945), forester in India from 18881919, becoming Conservator of Forests for India. No type was cited, but Haines stated 'Wild in the hill forests of the Mals of Puri, especially on the tops of ridges with heavy rainfall ! extending to Angul, in open forest, where it is less common ! Fl. July-Aug'. Haines' practise was to add the '!' when he had seen the plant in the wild in that locality, and does not always record the existence of a specimen.

Distinguishing features: this species is similar to C. circinalis in most respects, differing in the broader megasporophyll apex with longer teeth. (Fig. 2).

Distribution and habitat: Cycas spherica is from the Eastern Ghats in the state of Orissa in north-eastern and eastern peninsular India (Fig. 1), in dry forests and woodlands on hills.

Conservation status: poorly known. Donaldson (2003) status DD.

Selected specimens examined: INDIA: Orissa: Angul, Haines 4033 pp (male) (K); Puri, Haines 4033 pp (female) (K); "Hb Heyn", Wallich 8587B (K-W, K, LE); Presidency of Madras, Ganjam distr., Gullery [Galleri 20 6' 0" N, 84³4' 0" E], Gamble 13749, Jan 1884 (K); Gullery, per Hooker ¿ Thompson 101, 1855 (P); Athmallik [Athamallik $20^{\circ} 37^{\prime} \mathrm{N} 84^{\circ} 27^{\prime} \mathrm{E}$ ], Hathidharablock, Mooney 2867, (7 May 18 or 19 47). Tamil Nadu: Hategada, Gamble 13668, Jan 1883 (K); Krishnagiri town, cult in town, Lindstrom 856, 9 Jan 2002 (NSW); between Krishnagiri and Bangalore. 4 km from Sapali, Godeene, N 12³3.009', E 78 ${ }^{\circ} 11.522^{\prime} 545$ m ASL, Lindstrom 857, 9 Jan 2002 (NSW);

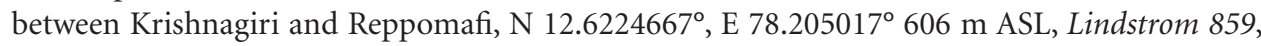
9 Jan 2002 (NSW). Karnataka: Santebachilas, Thiryanaihalle, N 12 ${ }^{\circ} 44.009^{\prime}$ E 76 $37.019^{\prime} 1029$ m ASL, Lindstrom 862, 10 Jan 2002 (NSW); ibid., N 12 44.009' E 76³7.019’1029 m ASL, Lindstrom 863, 10 Jan 2002 (NSW); ibid., N 12 46.236" 07634.839 " 983 m ASL, Lindstrom 864, 10 Jan 2002 (NSW); ibid., N 12 46.236’ E 76 34.839' 983 m ASL, Lindstrom 865, 10 Jan 2002 (NSW). Andra Pradesh: Palcondah [c. 13²0’ N 79³0’ E], Cleghorn s.n., Sep 1953 (E); 5 km North of Mamandur, $27 \mathrm{~km}$ from Tiraputi. N 13 43.609' E 79² 25.792' 380 m ASL., Lindstrom 867, 12 Jan 2002 (NSW); $5 \mathrm{~km}$ North of Mamandur, $27 \mathrm{~km}$ from Tiraputi. N 13 $43.330^{\prime} \mathrm{E} 79^{\circ}$ 25.459' 331 m ASL, Lindstrom 869, 12 Jan 2002 (NSW); 5 km North of Mamandur, $27 \mathrm{~km}$ from Tiraputi, N 13 43.330' E 79²5.459' 331 m ASL, Lindstrom 870, 12 Jan 2002 (NSW); 5 km North of Mamandur, 27 km from Tiraputi. N 13 43.330' E 79²5.459' $331 \mathrm{~m}$ ASL, Lindstrom 871, 12 Jan 2002 (NSW); Pulney Hills [KODAIKANAL 10 14' N 77²9' E], Sauliere 827 (K); Madurai distr., lower Pulneys, Anglade 1028 (K); Maradai Hills, Gamble 14597 (K); Madurai dist. Alagarkoil Range, Uppodapatti village, Lindstrom 878, 876, 15 Jan 2002 (NSW). 

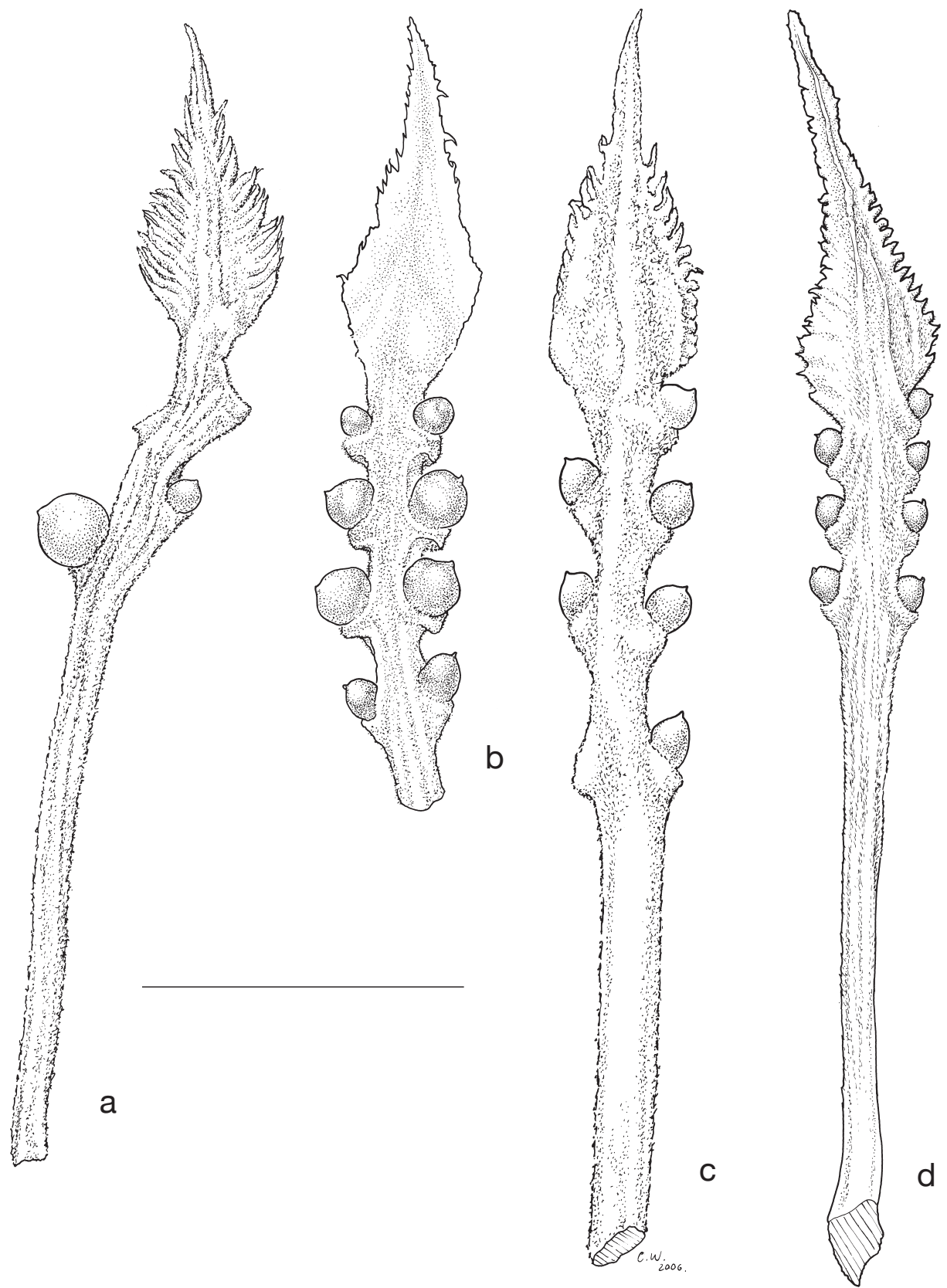

Fig. 2. Comparison of female sporophylls. a, C. spherica, b, C. indica, c, C. circinalis, d, C. nathorstii. (a from Haines 5877 (K), b from Cameron s.n. 10 Mar 1882 (K), c from image of Lindstrom 891, d from Thwaites 3689). Scale bar: a, b, c, d, $=5 \mathrm{~cm}$. 
5. Cycas annaikalensis Rita Singh and P.Radha (Singh \& Radha, Brittonia 58(2): 119123 (2006).

Type: India, Kerala, Palaghat, Annaikal hills, 940 m, Rita Singh, P. Radha and Prabha Sharma (0491) 0144, May 2003 (holo IPUH (CAL), iso DD).

Etymology: the specific epithet refers to the name of the locality, Annaikal hills where this population is located. In Malayalam, annai = elephant, and $\mathrm{kal}=$ rock.

Stems arborescent, approximately $5 \mathrm{~m}$ tall, 19-61 diam.; bark smooth, steel greyish without any persistent armour of leaf bases, cataphylls and leaf bases not persistent. Leaves bright green, semiglossy, 100-250 cm long, flat (not keeled) in section (opposing leaflets inserted at $180^{\circ}$ on rachis), with 200-240 leaflets, tomentum shedding as leaf expands.. Petiole 50-90 cm long, spinescent for 100\% of length, spines $0.9-3 \mathrm{~mm}$ long. Basal leaflets not gradually reducing to spines. Median leaflets simple, weakly discolorous; $260-350 \mathrm{~mm}$ long, $8-12 \mathrm{~mm}$ wide, inserted at $50-55^{\circ}$ to rachis; section flat; margins flat, not undulate; apex softly acuminate, not spinescent; midrib raised above, flat below, narrow. Cataphylls narrowly triangular, soft, thinly sericeous or lacking tomentum. Pollen cones sub-conical, yellowish orange prior to dehiscence, $30-50 \mathrm{~cm}$ long, 15-21 cm diam., microsporophyll lamina firm, not dorsiventrally thickened, 63$83 \mathrm{~mm}$ long, 18-26 mm wide, fertile zone 20-32 mm long, sterile apex 38-47 mm long, gradually raised and merging into spine. Seed cones open at pollination, open at seed set. Megasporophylls 9-25 cm long, persistently densely ferruginous-tomentose; ovules 2-10, glabrous; lamina triangular, 19-55 mm long, 13-40 mm wide, regularly dentate with 5-18 lateral spines 5-8 mm long, apical spine distinct from lateral spines, 3-25 mm long, 4-7 mm wide at base. Seeds 2-10 globose, 38-49 x 35-43 mm, sarcotesta green when young, becoming yellow at maturity, fibrous layer absent, sclerotesta smooth, spongy endotesta absent.

Historical notes: distinguished as a separate species during field surveys (2001-2004) by Indian botanist Rita Singh.

Conservation Status: Cycas annaikalensis occurs within the hilly forest region of Palaghat district, but the identity of the other sporadic populations in the vicinity of the type locality are yet to be confirmed. Cycas annaikalensis must be currently regarded as Data Deficient (DD) according to IUCN (2001).

Distinguishing features: Cycas annakailensis differs from C. spherica and C. circinalis in having steel grayish smooth trunk, the higher number of leaflets, the angle of attachment of the median leaflets to rachis and the larger microsporophyll. It differs from $C$. indica in the same features, and in the possession of a megasporophyll with a distinct terminal spine.

Distribution and habitat: Cycas annaikalensis is currently described from a single population of less than 100 individuals over an area of $100-250 \mathrm{~m}^{2}$ on the Annaikal hills near Palaghat at an altitude of $940 \mathrm{~m}$. Plants grow as an understorey element on steep slopes of coarse black humus soil with a thick canopy of tropical flowering trees. Assessing the habitat, it is assumed that this species may also occur in adjacent Reserve Forest areas, but comprehensive exploration has yet to be done to assess the number of populations and plants occurring in the region.

Selected specimens: INDIA: Kerala: Palaghat district, Annaikal, Oct 2001, 940 m Rita Singh, P. Radha \& Prabha Sharma, 0491, 0041-0052; May 2003, Rita Singh \& P.Radha (0491) 0075, 0076, 0118, 0119, 0120 (all IPUH); 
6. Cycas nathorstii J. Schust., Pflanzenr. 99: 76, Fig. 10E (1932).

Type: Sri Lanka, central and northern parts of the isle, Thwaites 3689 in Herb. BarbeyBoisser, 1866 (lecto here designated G, (female only); isolecto A, K, LE, P, fide Lindstrom 2002). This specimen was designated as the lectotype in Lindstrom and Hill (2002), however the specimen is comprised of male and female components and thus represents separate plants. This error is here corrected.

Etymology: honouring Swedish palaeobotanist Alfred Gabriel Nathorst (1850-1921), professor at the Natural History Museum in Stockholm.

Vernacular: Sinhala - madu (Schuster 1932, Bonta \& Osborne 2005).

Stems arborescent, to $4.5 \mathrm{~m}$ tall, 11-20 cm diam.; growing in soil or humus; base not strongly swollen; bark thick with persistent cataphylls and leaf bases. Leaves bright green, semiglossy, 160-180 cm long, flat (not keeled) in section, (opposing leaflets inserted at $180^{\circ}$ on rachis), with 140-170 leaflets, tomentum shedding as leaf expands; newly emerging leaves bright green, tomentum shedding early. Petiole $45-55 \mathrm{~cm}$ long (25-30\% of total leaf), glabrous, spinescent for $90-95 \%$ of length. Basal leaflets not gradually reducing to spines, 65-140 mm long. Median leaflets simple, weakly discolorous, $190-$ $310 \mathrm{~mm}$ long, $9-14 \mathrm{~mm}$ wide, narrowed to $3-4 \mathrm{~mm}$ at base (to $25-45 \%$ of maximum width), 17-20 $\mathrm{mm}$ apart on rachis; inserted at 55-80 to rachis; section flat; margins flat; apex softly acuminate, not spinescent; midrib raised above, raised below. Cataphylls narrowly triangular, soft, thinly sericeous or lacking tomentum, 50-60 mm long. Pollen cones narrowly ovoid, orange, c. $45 \mathrm{~cm}$ long, c. $15 \mathrm{~cm}$ diam.; microsporophyll lamina firm, not dorsiventrally thickened, 30-40 mm long, 15-22 mm wide, fertile zone 25-35 mm long, sterile apex c. $5 \mathrm{~mm}$ long; apical spine prominent, gradually raised, c. $10 \mathrm{~mm}$ long. Seed cones open at pollination, open at seed set. Megasporophylls 15-30 cm long, persistently brown tomentose; ovules 6-10, glabrous; lamina lanceolate, 40-65 mm long, 18-25 mm wide, shortly dentate with 26-40 lateral spines 1-4 mm long; apical spine distinct from lateral spines, $10-14 \mathrm{~mm}$ long, 4-8 $\mathrm{mm}$ wide at base. Seeds to $55 \mathrm{~mm}$ long, to $40 \mathrm{~mm}$ wide, flattened-ovoid; sarcotesta yellow, fibrous layer absent; sclerotesta smooth; spongy endotesta absent.

Historical notes: the upland cycad from Sri Lanka has been generally known as C. circinalis (Trimen 1898), and was in fact one element of the protologue of the latter (Linnaeus 1753; Fl. Zel.). German historian and sometime botanist Julius Schuster distinguished C. nathorstii from C. circinalis in 1932 on the basis of specimens collected by George Thwaites and distributed to European herbaria by Swiss botanist and philanthropist William Barbey-Boissier (1842-1914). Thwaites (1812-1882) was superintendent of the Royal Botanic Garden at Peradeniya in Ceylon from 1849-1880. Collection detail cited was "Ceylon: Thwaites 1866 n. 3689 in Herb. Barbey-Boissier." The Barbey-Boissier herbarium and types are in G, including this specimen. This may not have been the specimen examined by Schuster, as it has no annotation by him and was filed as undetermined. Schuster's types were mainly in B, and were destroyed during WW2. This sheet includes both leaflets and megasporophylls, and is here designated the lectotype. Schuster's work has been largely (rightly) ignored, including this taxon, although, in this case, a valid distinction exists.

De Laubenfels and Adema (1998) included C. nathorstii in the synonymy of C. spherica, but also placed some Sri Lankan collections of the same taxon in C. circinalis.

Distinguishing features: distinguished from C. circinalis and C. spherica by the more 
robust habit, narrower, dull leaflets and larger male cones with longer and more curved apical spines on microsporophylls. C. nathorstii is distinguished from C. zeylanica by the more closely spaced and more chartaceous leaflets, the shorter, softer and less pilose cataphylls and lack of spongy endotesta. It is distinguished from C. circinalis by the bright green new growth, whereas new growth is bluish in C. circinalis.

Distribution and habitat: C. nathorstii occurs in inland and upland forests in the north of Sri Lanka, and on flat land in the east of Tamil Nadu in India (Fig. 1), usually in somewhat drier sites.

Conservation status: India: like all cycads in Tamil Nadu this species has suffered greatly from stem cutting for local medicine. Several populations have been depleted to only a very few scattered individuals. As the lowland is very attractive agricultural land populations have been destroyed to make way for human populations. It must be regarded as Endangered (IUCN 2001 Red List category EN). Sri Lanka: Still locally frequent, although not in great numbers, this species is regarded as vulnerable (IUCN 2001 Red List category VU). It is known to be present in reserves, but political instability makes assessment difficult and future status uncertain.

Selected specimens examined: INDIA: Tamil Nadu: Chuingleput distr. [CHINGLEPUT $12^{\circ} 42^{\prime}$ N 79 59' E],"Madras" Gamble 17052, Nov 1885 (K); Pattamcattah [? PATTUKKOTTAI 10²6' N $79^{\circ} 19^{\prime} \mathrm{E}$ ], herb Wight 2756 pp, Oct 1835 (K, LE, G); 4 km from Tiruporor towards Changelpet, $\mathrm{N} 12^{\circ}$ 42.842' E 800 09.394' 24 m ASL, Lindstrom 896, 18 Jan 2002 (NSW); Tamil Nadu, 4 km from Tiruporor towards Changelpet, N $12^{\circ} 43.047^{\prime}$ E 80 09.278' 17 m ASL, Lindstrom 897, 18 Jan 2002 (NSW). SRI LANKA: between Kuda Patessa and Maha Patessa, Cooray \& Wirawan 1145, 15 Jul 1969 (A, K, L, NY); NW Province, Puttalam district, Wilpattu National Park, Kudu patassa, Davidse 8237 \& Sumithraarachi, 1 Nov 1974 (BRI, K, L); 2 miles [3.2 km] E of Bible, Fosberg \& Sachet 53148, 28 Nov 1970 (K, NY); Manerangata district, Bibile, Hepper \& de Silva 4723, 18 Jul 1972 (K); Ceylon, herb. P. Herm. (L); ridge S of Na-Ulpota, Jayasuriya 1278, 8 Aug 1973 (K); Moraragale district, Nilgala, Gal Oya National park, Jayasuriya 1951, 1 May 1975 (L); Gampaha district, N of Gampaha, NE of Dunagaha, Diwulepitiya, Rassapana village, Lindstrom s.n. (NSW 440049), 1997 (NSW); Mandae, Oldmanas 53 (L); hort. Kew. ex Ceylon, Thwaites 423, $1875(\mathrm{~K})$.

\section{Cycas indica A.Lindstrom \& K.D.Hill, sp. nov.}

A Cycade circinali megasporophyllis reductis spinis apicalibus lateralibusque reductis, caudice surculari differt.

Type: India: Mysore, Hassan distr., Nagpuri, Chick Tirupathii, Saldanha 15197, 8 Oct $1970(\mathrm{E})$.

Etymology: the epithet is in reference to the species endemic occurrence in India.

Stems arborescent, to $4 \mathrm{~m}$ tall, 10-23 cm diam.; growing in soil or humus; base not strongly swollen; bark thin and smooth, cataphylls and leaf bases persistent. Leaves deep green, semiglossy, 97-133 cm long, flat (not keeled) in cross-section, (opposing leaflets inserted at $180^{\circ}$ on rachis), with $50-71$ leaflets, indumentum present on petiole and leaflets. Petiole $28-32 \mathrm{~cm}$ long (25-35\% of total leaf length), spinescent for 30\%-90\% of length. Basal leaflets not gradually reducing to spines, 72-110 mm long. Median leaflets simple, discolorous, $120-240 \mathrm{~mm}$ long, 7-8 $\mathrm{mm}$ wide, narrowed to 3-4 $\mathrm{mm}$ at the base (35-50\% of total width), spaced at $12-15 \mathrm{~mm}$ on rachis; margins flat; midrib raised above, flat below. Cataphylls narrowly triangular, soft, very finely tomentose, 50-80 mm long. Pollen cones narrowly ovoid, yellow, c. 30-40 cm long, c. $15 \mathrm{~cm}$ diam.; microsporophyll 


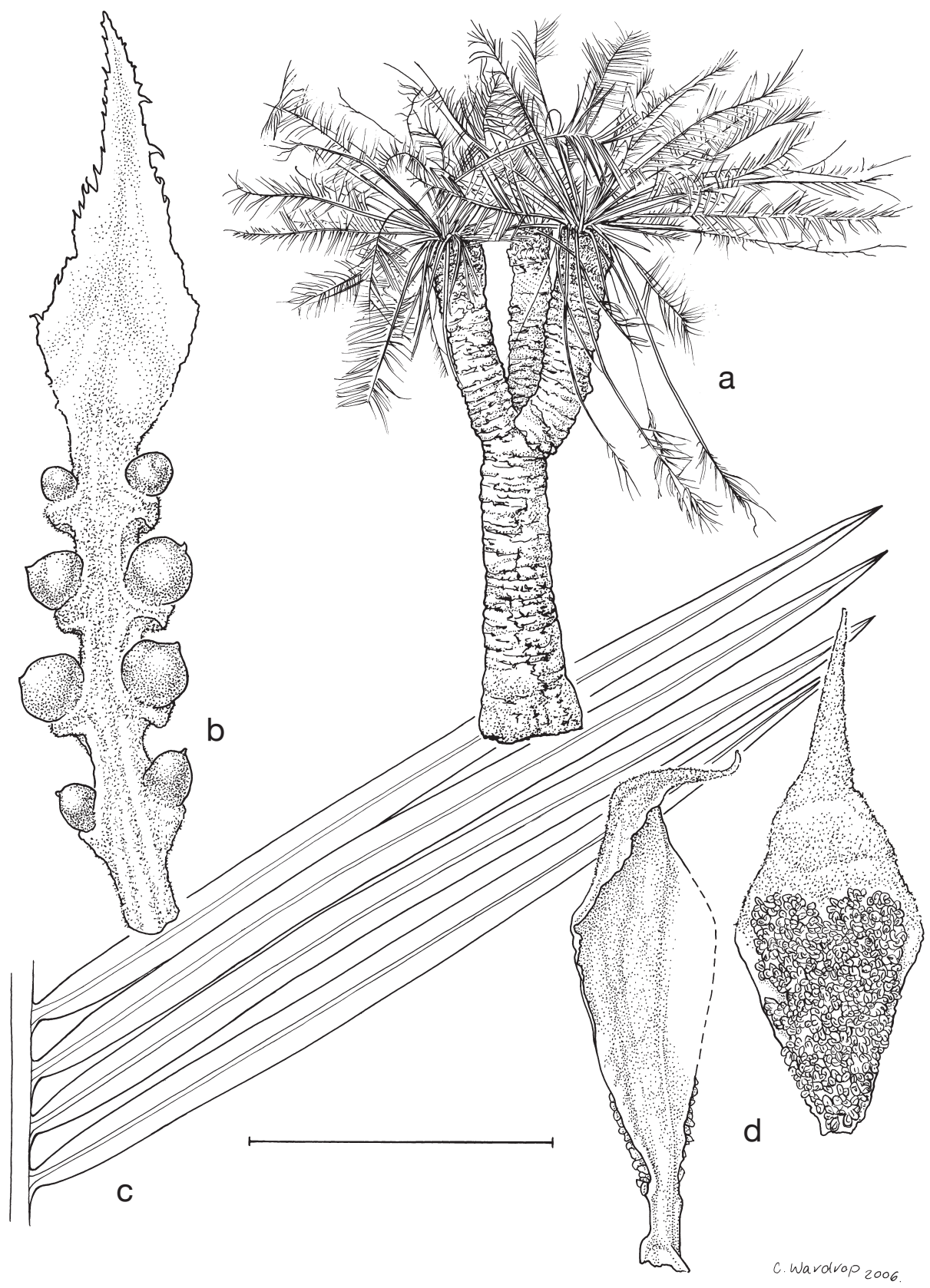

Fig. 3. Cycas indica. a, sketch of habit. b, female sporophyll. c, part of leaf. d, e, male sporophyll. (a from Lindstrom 864 slide, b from Cameron s.n. 10 Mar 1882 (K), c d e from Saldanha 15197) Scale bar: $\mathrm{a}=$ No scale, $\mathrm{b}=4 \mathrm{~cm}, \mathrm{c}=5.45 \mathrm{~cm}, \mathrm{~d}=3 \mathrm{~cm}, \mathrm{e}=3 \mathrm{~cm}$. 
lamina firm, not dorsiventrally thickened, c. $66 \mathrm{~mm}$ long, c. $28 \mathrm{~mm}$ wide, fertile zone c. $23 \mathrm{~mm}$ long, sterile apex merged with spine, apical spine prominent, sharply upturned, c. $41 \mathrm{~mm}$ long. Seed cones open at pollination, open at seed set. Megasporophylls $18 \mathrm{~cm}$ long, brown tomentose; ovules 6, glabrous; lamina 25-55 mm long, 19-22 mm wide with less than 10 short irregular lateral spines to $2 \mathrm{~mm}$ long; apical spine not distinct from lateral spines, 1-3 mm long, 1-3 mm wide at base. Seeds globose, 32-35 mm long, 28-30 mm wide; sarcotesta yellow at maturity, fibrous layer absent; sclerotesta smooth; spongy endotesta absent (Fig. 3).

Historical notes: this is the entity that has been referred to in literature (Pant 1962, 1973; Singh 2006) as Cycas circinalis var. swamyi, but this name has never been validly or legitimately published. Reference has been made to the abnormal branching habit (Pant 1962, 1973), but no rigorous comparisons have been made with C. circinalis growing in other localities.

Distinguishing features: similar to $C$. circinalis but distinct in the short apical spine and compact lamina with few, short (or almost lack of) lateral spines on the megasporophyll (Fig. 2), the shorter and narrower leaflets, overall shorter leaves and a distinct suckering growth habit. It shares the globose seeds with C. spherica.

Distribution and habitat: restricted to the Hassan district in Karnataka State (Fig. 1). Common on flat sandstone or on quartzite-dominated areas. This species forms extensive colonies.

Conservation status: not known (DD - IUCN 2001).

Selected specimens examined: INDIA: Karnataka: 20 to 35 miles from Bangalore, "where ranges of Western Ghats meet tablelands", Cameron s.n. (K - 3 sheets, dated 4 Mar 1884, 10 Mar 1882 and Apr 1884); Mysore, Buchanan per Wallich $8587 B$ (K, BM).

Subsection Rumphiae K.D.Hill, Austral. Syst. Bot. 7: 548 (1994).

Type: C. rumphii Miq., Bull. Sci. Phys. Nat. Neerl. 2: 45 (1839).

This subsection is uniquely defined by the presence of a layer of spongy tissue within the seed. Another potentially synapomorphic character defining this group is the 2year seed maturation period, although this has been confirmed only for C. seemannii, C. thouarsii and C. bougainvilleana K.D.Hill. All other species of Cycas for which data is available have a maturation period of less than one year.

Distribution is very wide, extending from Africa to Fiji and Tonga, and from New Guinea north to southern coastal Indochina. One species occurs in India, in the Andaman and Nicobar islands only.

Taxonomy of the group is difficult, and all species in the C. rumphii complex have appeared in the literature erroneously as C. circinalis at some stage (see Hill 1994).

The spongy endotesta causes seeds to be buoyant, and has been proposed as a dispersal mechanism (Dehgan and Yuen 1983). This dispersal mechanism has been interpreted as a cause of the taxonomic complexity of this group, with successive colonisation events producing the high local variability in some populations and the very different forms sometimes occurring in close proximity (Hill 1994, Fosberg and Sachet 1975). 
8. Cycas zeylanica (J. Schust.) A. Lindstrom \& K.D. Hill, Novon 12(2): 238-239 (2002).

Cycas rumphii subsp. zeylanica J. Schust., Pflanzenr. 99: 75, Fig. 10 C-D, 11 M (1932).

Type: Sri Lanka, 1866, Thwaites 3862 in Herb. Barbey-Boissier (lecto G, (female only) isolecto A, K, LE) (Lindstrom \& Hill 2002).

Literature: Trimen 1898 (as C. rumphii), Rendle 1900 (as C. rumphii), Raizada \& Sahni 1960 (as C. rumphii).

Etymology: from Zeylona, the Latinised rendering of Ceylon (Sri Lanka), from where the type of this species was collected.

Vernacular: Maha-madu (Sri Lanka).

Stems arborescent, 2.3-3.1 m tall, 13-20 cm diam.; growing in soil or humus; base not strongly swollen; bark thin and smooth; (with c. 30 leaves in crown), cataphylls and leaf bases not persistent. Leaves bright to deep green, semiglossy, 140-190 cm long, flat (not keeled) in section, (opposing leaflets inserted at $180^{\circ}$ on rachis), with $70-100$ leaflets, with white or orange tomentum shedding as leaf expands; rachis consistently terminated by paired leaflets. Petiole $50-70 \mathrm{~cm}$ long (30-40\% of total leaf), glabrous, spinescent for $30-100 \%$ of length. Basal leaflets not gradually reducing to spines, 190-200 mm long. Median leaflets simple, strongly discolorous, inserted at 50-60 to rachis, $180-300 \mathrm{~mm}$ long, $12-15 \mathrm{~mm}$ wide, narrowed to $6-7 \mathrm{~mm}$ at base (to $40-50 \%$ of maximum width), 22-27 mm apart on rachis; section flat; margins slightly recurved; apex acute, not spinescent; midrib raised above, flat below. Cataphylls linear, pungent, pilose, 100-120 mm long. Pollen cones fusiform, orange-brown, c. 30-40 cm long, c. $10 \mathrm{~cm}$ diam.; microsporophyll lamina firm, dorsiventrally thickened, 35-45 mm long, 17-19 mm wide, fertile zone 30-40 mm long, sterile apex 3-5 mm long; apical spine prominent, sharply upturned, 3-10 $\mathrm{mm}$ long. Seed cones open at pollination, open at seed set. Megasporophylls 17-30 cm long, persistently brown tomentose; ovules 2-4, glabrous; lamina lanceolate, 60-120 mm long, 10-17 mm wide, obscurely dentate with 6-12 lateral bumps or short spines to $2 \mathrm{~mm}$ long; apical spine distinct from lateral spines, 40-60 mm long, 3-7 $\mathrm{mm}$ wide at base. Seeds flattened-ovoid, 60-70 $\mathrm{mm}$ long, 45-55 mm wide; sarcotesta orange-brown, fibrous layer absent; sclerotesta smooth; spongy endotesta present.

Historical notes: collection detail cited was "Ceylon: Thwaites 1866 n. 3862 in Herbar. Barbey-Boissier." Schuster's herbarium and types were in B, and were destroyed in WW2. The Barbey-Boissier herbarium and types are in G, including this collection. Three sheets exist, with microsporophylls, megasporophylls and leaflets, each on a separate sheet. More than one plant is clearly involved, and it is impossible at this stage to associate the leaf specimen with either of the fertile specimens. These may not have been the specimens examined by Schuster, as they have no annotations. The sheet bearing the megasporophylls has been designated the lectotype.

Distinguishing features: allied to both $C$. thouarsii and C. edentata, sharing the characters of seeds lacking an apical wing and microsporophylls with an apical spine. Cycas zeylanica is distinguished by the abundant long and pungent cataphylls and widely spaced leaflets.

Distribution and habitat: known from Sri Lanka, where apparently now a rare species in southern coastal regions, and the Andaman and Nicobar groups, where more abundant (Fig. 1). The habitat is in littoral forest near the sea in sandy soil. 
Conservation status: India. The species is widespread and common on the Andamans and Nicobar islands. But although still growing in large populations at several locations, severe damage has been done by repeated strong cyclones. The recent development of seaside resorts on the islands has also had an impact on some populations and several previously large populations have been eradicated to make space for tourist accommodations. There are populations within protected areas as well as in off-limit, military areas. Recommended IUCN Red List category would be Vulnerable (VU - IUCN 2001). Sri Lanka. Populations have been totally destroyed and a survey done by the first author failed to find any viable regenerating populations. Only widely scattered, large, old specimens remained. No plants were found within any protected areas. The 2005 tsunami hit the coast of Sri Lanka and seriously damaged the only known narrow strip of land where the last scattered individuals existed. Although no recent post tsunami survey has been conducted it is very likely that most if not all remaining plants are now dead, either by direct hit of the wave and debris or bulldozed by the cleaning crew. The correct IUCN Red List category for the species on Sri Lanka should be Critically Endangered (CR) or possibly Extinct (EX). (IUCN 2001).

Selected specimens examined: INDIA: South Andaman, Kurz s.n. (K, P); hort. Kew, raised from seed coll. Nicobars by Col. Nan in 1875, leg. ign., 1881 (K); South Andaman, Liebig s.n. (E); Havelock island, E. coast, beach No. 5, 2 m ASL, tall evergreen littoral forest, app. $50 \mathrm{~m}$ from the beach, Lindstrom 357, 2 Dec 2000 (SING), cult. near the jetty, 5 m ASL, Lindstrom 359, 2 Dec 2000 (SING); W. coast, beach No.7, 3 m ASL, tall secondary evergreen littoral forest, Lindstrom 365 , 3 Dec 2000 (SING); Kodiaghat, beach vegetation, sandy soil, sea level, few plants, Bulakrishnan 382, 25 Sep 1973 (SING); Rangat, Middle Andaman, Kirit Ram 3806, Feb-Mar 1934 (E). SRI LANKA: Araiya Mawtha, Maddawattha, Mataya, wild near the seashore along a stream, $27 \mathrm{~m}$ ASL, Lindstrom 287, 10 Jun 2000 (SING); cultivated along the road, $31 \mathrm{~m}$ ASL, Lindstrom 288, 10 Jun 2000 (SING); Hikkaduwa, Dewadalla, Wauleguda, cult. Lindstrom 289, 11 Jun 2000 (SING); Wtage, Alangama, cult., 11 Jun.2000 Lindstrom 290 (SING); cult. Peradinya, Lindstrom s.n., 1997 (NSW 440048) (NSW).

\section{Acknowledgments}

Mr. Kampon Tansacha, the owner and Director of Nong Nooch Tropical Botanical Garden, Thailand is most gratefully acknowledged for his relentless encouragement and full sponsorship of the field trips. The Slade Foundation of Sydney is also thanked for assistance with travel and field studies. The staff of the Royal Botanic Gardens, Sydney, have been of invaluable assistance, and this would not have been published without them, Leonie Stanberg in particular. Illustrations are by Catherine Wardrop and Lesley Elkan. Peter Wilson is thanked for assistance with Latin. Juliet Wege is thanked for locating specimens at Kew while Australian Botanical Liaison Officer.

\section{References}

Amoroso VB (1986) Morphological study of the sporophylls of Philippine Cycas. Philippine Journal of Science 115(3): 177-198.

Anon. (1828) Botanical Magazine 55: t. 2826, 2827.

Beddome RH (1869) The forester's manual of botany for southern India. (Gantz Bros: Madras)

Bonta M \& Osborne R (2007) Cycads in the Vernacular in Osborne R (ed.) Proceedings of the Seventh International Conference on Cycad Biology. Memoirs of New York Botanical Garden Vol. 99 (in press). 
Borell GW (1989. An annotated checklist of the flora of Kairiru Island, New Guinea. (Borell, Marcelin College: Victoria)

Burkill J (1901) The flora of Vavua, one of the Tonga islands. Journal of the Linnaean Society, Botany 35(242): 20-65.

Chen CJ, Zhou L, Yang SY \& Han ZS (1995) Cycas in China, with notes on its conservation status. Pp. 177-191 in Vorster P (ed.) Proceedings of the Third International Conference on Cycad Biology. (Cycad Society of South Africa, Stellenbosch)

Chen CJ \& Stevenson DW (1999) Cycadaceae. Pp. 1-7 in Wu ZY \& Raven PH (eds) Flora of China, vol 4. (Science Press, Beijing \& Missouri Botanical Garden Press: St Louis)

Cheng WC, Fu LK \& Cheng CY (1975) Gymnospermae Sinicae. Acta Phytotaxonomica Sinica 13(4): 81-82.

De Candolle AP (1868) Cycadaceae. Pp. 522-548 in de Candolle AP (ed.) Prodromus Systematis Naturalis Regni Vegetabilis 16(2). (Treuttel et Wurtz: Paris)

De Laubenfels DJ \& Adema F (1998) A taxonomic revision of the genera Cycas and Epicycas gen. nov. (Cycadaceae). Blumea 43: 351-400.

De Laubenfels DJ (1972) Cycadaceae. Pp. 3-7 in Humbert H \& Leroy J-F (eds) Flore de Madagascar et des Comoros: Gymnospermes. (Museum Nationale D'Histoire Naturelle: Paris)

Dehgan B \& Yuen CKH (1983) Seed morphology in relation to dispersal, evolution and propagation of Cycas. Botanical Gazette 144(3): 412-418.

Donaldson, J. S. (ed.) (2003) Cycads. Status Survey and Conservation Action Plan. IUCN/SSC Cycad Specialist Group (IUCN: Gland and Cambridge)

Fischer CEC (1928) Flora of the presidency of Madras. (Adlard \& Son: London)

Fosberg FR \& Sachet M-H (1975) Flora of Micronesia, 1: Gymnospermae. Smithsonian Contributions to Botany 20: 1-15.

Foxworthy FW (1911) Philippine gymnosperms. The Philippine Journal of Science 6(3): 149152

Gaudichaud-Beaupre C (1829) Botanique. Pp. 432-441 in de Freycinet L Voyage autour du monde, S.M. Uranie. (Pillet: Paris)

Gibbs LS (1914) Cycadaceae. In a contribution to the flora and plant formations of Mount Kinabalu and the highlands of British North Borneo. Journal of the Linnean Society, Botany. 42(285): 1-240.

Grierson AJC \& Long DG (1983). Flora of Bhutan, vol. 1. (Royal Botanic Gardens Edinburgh: London)

Griffith W (1854a) Notulae ad Plantas Asiaticas, vol. 4. (Bishops College Press: Calcutta)

Griffith W (1854b) Icones plantarum asiaticum, vol. 4. (Coshan: Calcutta)

Haines HH (1924) The Botany of Bihar and Orissa 6: 1228. (Adlard: London)

Hamilton F (1826) Commentary on the Herbarium Amboinense. Memoirs of the Wernerian National Historical Society 5(2): 322-324.

Hemsley WB (1895) Descriptions of some new plants from eastern Asia, chiefly from the island of Formosa, presented by Dr. Augustine Henry, F.L.S., to the Herbarium, Royal Gardens, Kew. Annals of Botany 33: 143-160

Hill KD \& Yang SL (1998) The genus Cycas (Cycadaceae) in Thailand. Brittonia 51: 48-73.

Hill KD (1994) The Cycas rumphii complex (Cycadaceae) in New Guinea and the Western Pacific. Australian Systematic Botany 7(5): 3-567.

Hill KD (1995) The genus Cycas (Cycadaceae) in the Indian region, with notes on the application and typification of the name Cycas circinalis. Taxon 44: 23-31.

Hill KD (1995) Infrageneric relationships, phylogeny and biogeography of the genus Cycas (Cycadaceae). Pp 139-162 in Vorster P (ed.) CYCAD 93, The 3rd International Conference on Cycad Biology, Proceedings. (Cycad Society of South Africa: Stellenbosch)

Hill KD (1998) The Cycad Pages. Royal Botanic Gardens Sydney. http://plantnet.rbgsyd.nsw. gov.au/PlantNet/cycad/index.html

Hill KD (2004a) Character evolution, species recognition and classification concepts in the Cycadaceae. Pp. 23-44 in Walters T \& Osborne R (eds) Cycad classification concepts and recommendations. (CABI Publishing: Wallingford) 
Hill KD (2004b) An analysis of morphological characters used in classification of the Cycadaceae. Pp 6-29 in Lindstrom AJ (ed.) The Biology, Structure \& Systematics of the Cycadales Proceedings of the Sixth International Conference on Cycad Biology, Thailand, 29 July-3 Aug, 2002. (The Nong Nooch Tropical Botanical Garden: Sattahip)

Hill KD \& Vatcharakorn P (1998) The Cycads of Thailand. Pp. 178-190 in Hodel DR (ed.) The Palms and Cycads of Thailand. (Kampon Tansacha, Nong Nooch Tropical Garden: Thailand)

Ho P \& Duong N (1960) Cay-co mien nam Viet-nam. (Ministry of National Education: Saigon)

IUCN (2001) IUCN Red List Categories and Criteria : Version 3.1. IUCN Species Survival Commission. (IUCN: Gland)

Jarvis CE, Barrie FR, Allan DM \& Reveal JL (1993) A list of Linnaean generic names and their types. Regnum Vegetabile 127, 1-100.

Jones DL (1993) Cycads of the World. (Reed: Chatswood)

Kurz S (1877) Forest flora of British Burma, vol 2. (Government printer: Calcutta)

Leandri J (1931) Cycadaceae. Pp. 1085-1092 in Lecomte MH \& Gagnepain F (eds) Flore Generale de L'Indo-Chine, vol. 5. (Masson et Cie: Paris)

Lindstrom AJ \& Hill KD (2002) Notes on the species of Cycas (Cycadaceae) from Sri Lanka and Islands of the Andaman Sea. Novon 12: 237-240.

Lindstrom AJ (2002) Circumscription and lectotypification of Cycas rumphii (Cycadaceae). Brittonia 54(4): 305-309.

Linnaeus C (1747) Flora Zeylanica. (Holmiae [Stockholm]: L. Salvii)

Linnaeus C (1753) Species Plantarum, vol. 1. (1960 facsimile). (Engelmann: Weinheim)

Linnaeus C (1754) Genera Plantarum, 5th edition (1934 facsimile). (Shokobutu Bunken: Tokyo)

McNeill J, Barrie FR Burdet H-M, Demoulin V, Hawksworth DL, Marhold K, Nicholson DH, Prado J, Silva PC, Skog JE, Wiersema JH, Turland NJ (eds) (2006) International Code of Botanical Nomenclature (Vienna), adopted by the Seventeenth International Botanical Congress, Vienna, Austria, July 2005. Regnum Vegetabile 146. (Gantner: Ruggell)

Miquel FAW (1839) Melanges botaniques. Bulletin des Sciences Physiques et Naturelles en Neerlande 2: 36, 44-46.

Miquel FAW (1842) Monographia cycadearum. (Rhenum: Utrecht)

Miquel FAW (1851) Analecta Botanica Indica. (Sulpke: Amsterdam)

Miquel FAW (1868) Nouveaux matériaux pour servir à la connaissance des Cycadées. Archives Néerlandaises des Sciences Exactes et Naturelles 3(5): 193-254, 403-427.

Paijmans K (1976) Vegetation. Pp. 23-105 in Paijmans K (ed.) New Guinea Vegetation. (Elsevier: Amsterdam)

Pant DD (1962) Cycas and the Cycadales. (Central Book Depot: Allahabad)

Pant DD (1973) Cycas and the Cycadales, 2nd edition. (Central Book Depot: Allahabad)

Pant DD, Singh R \& Chauhan DK (1994) On Cycas pectinata Hamilton from north-east India. Encephalartos 38: 17-30.

Pilger R (1926) Cycadaceae. Pp. 44-82 in Engler A (ed.) Die naturlichen pflanzenfamilien, edition 2, 13. (Duncker \& Humblot: Berlin)

Raizada MB \& Sahni KC (1960) Living Indian gymnosperms part 1: Cycadales, Ginkgales and Coniferales. Indian Forestry Records: Botany. (n.s). Bot. 5. (1-4): 73-150.

Regel E (1863) Cycas riuminiana Porte. Gartenflora 12: 16-17.

Rendle AB (1900) Gymnosperms. Pp. 193 in Andrews CW (ed.) A monograph of Christmas Island. (Longmans: London)

Rheede HA (1682) Hortus indicus malabaricus, vol. 3. (van Someren, van Dyck \& Boom: Amsterdam)

Ridley H (1925) Cycadaceae. Flora of the Malay Peninsula 5: 283-285.

Roxburgh W (1814) Hortus Bengalensis. (Mission Press: Serampore)

Roxburgh W (1832) Flora Indica and descriptions of Indian plants. (Thacker: Calcutta) 
Schuster J (1932) Cycadaceae. Pp. 1-168 in Engler A (ed.) Das Pflanzenreich 99 (4,1). (Engelmann: Leipzig)

Sealy JR (1975) William Roxburgh's collection of paintings of Indian plants. Endeavor 34: 8489.

Singh R (2007) Cycas annaikalensis, a new species from the Western Ghats of India, with discussion on the specific limits of C. circinalis in Osborne R (ed.) Proceedings of the Seventh International Conference on Cycad Biology. Memoirs of New York Botanical Garden Vol. 99 (in press).

Singh R \& Radha P (2006) A new species of Cycas from the Malabar Coast, Western Ghats, India. Brittonia 58(2): 119-123.

Smitinand T (1971) The genus Cycas Linn. (Cycadaceae) in Thailand. Natural History Bulletin of the Siam Society 14 (1-2): 163-175.

Smitinand T (1972) Cycadaceae. Pp. 185-192 in Smitinand T \& Larsen K Flora of Thailand, vol. 2(2). (Applied Scientific Corporation of Thailand: Bangkok)

Stapf O (1916) Cycas Thouarsii. Kew Bulletin of Miscellaneous Information 1-8.

Stevenson DW (1992) A formal classification of the extant cycads. Brittonia 44: 220-223.

Stone BC (1970) The Flora of Guam. Micronesica 6.

Suvatabandhu K (1961) The living gymnosperms of Thailand. Journal of the National Research Council Thailand 2: 59-62.

Tang WT, Yang SL \& Vatcharakorn P (1997) Cycads in Thailand. (Nong Nooch Garden: Chonburi)

Thiselton-Dyer WT (1881) Cycads of Indian Peninsula. Gardeners Chronicle, Aug 27: 270.

Thiselton-Dyer WT (1883) On a new species of Cycas from southern India. Transactions of the Linnaean Society London. Botany. series 2. 2: 85-86, pl. 17.

Thiselton-Dyer WT (1888) Cycadaceae. Pp. 655-658 in Hooker WJ Flora of British India, vol. 5. (Reeve: London)

Thiselton-Dyer WT (1902) Cycadaceae in Forbes FB \& Hemsley WB, An enumeration of the plants of China. Journal of the Linnean Society, Botany 26: 559-561.

Thiselton-Dyer WT (1905) Cycas micholitzii. Gardeners Chronicle series 3. 38(973): 142-144.

Thunberg CP (1784) Flora Japonica. 229. (Mülleriano: Lipsiae)

Trimen H (1898) Flora of Ceylon, vol. 4. (Dulau: London)

Walter KS \& Gillett HJ (eds) (1998) 1997 IUCN Red List of Threatened Plants. Compiled by the World Conservation Monitoring Centre. (IUCN - The World Conservation Union: Gland)

Walters T \& Yang SL (1994) The cycads of China - findings from the Montgomery Foundation / Fairchild Tropical Garden 1992 expedition. Pp. 6-11 in Tang W (ed.) The Cycads of China. Journal of the Cycad Society, vol. 1.

Wang DY (1996) Systematic classification and taxonomy. Pp. 9-142 in Wang F-X \& Liang H-B (eds) Cycads in China. (Guangdong Science and Technology Press: Guangdong)

Warburg O (1900) Cycadaceae. Pp. 178-181 in Warburg O (ed.) Monsunia. (Engelmann: Leipzig)

White CT (1922) A contribution to our knowledge of the flora of Papua. Proceedings of the Royal Society of Queensland 34: 5-65.

Whitelock LM (2002) The Cycads. (Timber Press: Portland)

Wijnands DO (1986) Linnaeus's attitude towards cultivated plants. Acta horticulturae 182: 67-78.

Yuncker TG (1959) Plants of Tonga. Bernice P. Bishop Museum Bulletin 220. (Bernice P. Bishop Museum: Honolulu)

Zamora PM \& Co L (1986) Guide to Philippine flora and fauna 2: Descriptions of Gymnosperm species. (Ministry of Natural Resources \& University of the Philippines: Quezon City)

Zhou L, Yang SY \& Zhou Z (1990) Investigation of the natural community of Cycas panzihuaensis L.Zhou \& S.Y.Yang. Memoirs of the New York Botanical Gardens 57: 148-151. 